\title{
Evaluation of canola seeds of different cultivars with special emphasis on the quantification of erucic acid and glucosinolates
}

\author{
By Sadia Ali ${ }^{1}$, Farooq Anwar ${ }^{1 \star}$, Samia Ashraf ${ }^{1}$, Farah Naz Talpur ${ }^{2}$ and Muhammad Ashraf ${ }^{3}$ \\ 1 Department of Chemistry and Biochemistry, University of Agricultur, Faisalabad-34080 Pakistan. \\ ${ }^{2}$ National Center of Excellence in Analytical Chemistry, University of Sindh, Jamshoro-76080-Pakistan. \\ ${ }^{3}$ Department of Botany, University of Agriculture, Faisalabad-34080, Pakistan. \\ * Corresponding author:fqanwar@yahoo.com
}

\section{RESUMEN}

Evaluación de semillas de canola procedentes de diferentes variedades con especial énfasis en la cuantificación de ácido erúcico y glucosinolatos.

Este estudio describe de la caracterización de semillas y de sus aceites de cinco cultivos locales de canola: Zafar2002, Bulbul (Frontier), Dunkeld, Oscar y Con 11. El contenido de aceite de las semillas de canola varió entre un 34.3 y un $39.3 \%$. Los niveles de proteína, fibra, ceniza y humedad fueron $22.1-41.0,12.0-14.0,3.0-3.5$ and $4.0-7.5 \%$, respectivamente. El contenido de glucosinolatos (GSL) en las semillas de canola examinadas varió entre un 49.7 y un 78.1 $\mathrm{mmol} \mathrm{g}^{-1}$. El aceite de canola extraído tuvo un índice de yodo de 118.2-124.6 g de l/100g de aceite; índice de refracción $\left(40^{\circ} \mathrm{C}\right), 1.460-1.464$; densidad $\left(24^{\circ} \mathrm{C}\right), 0.914-0.919 \mathrm{mg} \mathrm{mL}^{-1}$; índice de saponificación, 187-195; materia insaponifiable, 0.51-1.10\%; acidez (\% como ácido oleico), 0.40-1.40, y color (cubeta de 1 pulgada), 1.35-1.73 R + 21.0-38.0 Y. El índice de peróxido (meq/ $\mathrm{kg}$ de aceite) y la extinción específica a 232 and $270 \mathrm{~nm}$ fueron 2.00-7.08, 2.17-3.16 and 0.440.91 , respectivamente. El aceite de las semillas de los cinco cultivos de canola contenían principalmente ácido oleico (C18:1), ácido linoleico (C18:2) and ácido linolenico (C18:3) a unos niveles de 49.16-62.14, 14.61-23.45 and 6.97-9.10\%, respectivamente. Las concentraciones de ácido palmítico (C16:0), ácido esteárico (C18:0), ácido erúcico (C22:1) y ácido gadoleico (C20:1) variaron entre 3.47 y $6.00,1.51$ y 2.10 , trazas y 13.03 , y 1.30 y $10.63 \%$, respectivamente. Una pequeña cantidad de ácido araquídico (20:0) con una contribución por debajo del 1\% fue también detectada. El contenido de tocoferoles ( $\alpha, \gamma$, and $\delta$ ) en los aceites de canola fue de 77.1-270.3, 191-500, 3.5-15.6 $\mathrm{mg} \mathrm{kg}^{-1}$, respectivamente. La presencia de niveles relativamente altos de ácido erúcico y GSL en el presente análisis de la canola incide en la necesidad de reducir el contenido de estos dos constituyentes anti-nutricionales en los cultivares investigados.

PALABRAS CLAVE: Ácido erúcico - Canola - Caracterización - Estabilidad oxidativa - Glucosinalatos - Propiedades físico-químicas - Tocoferoles.

\section{SUMMARY}

Evaluation of canola seeds of different cultivars with special emphasis on the quantification of erucic acid and glucosinolates.

This study reports the characterization of the seeds and seed oils of five locally grown canola cultivars: Zafar-2002, Bulbul (Frontier), Dunkeld, Oscar and Con-11. The oil contents from canola seeds ranged from 34.3 to $39.3 \%$. The levels of protein, fiber, ash and moisture were found to be 22.1-41.0, 12.0-14.0, 3.0-3.5 and 4.0-7.5\%, respectively. The glucosinolate (GSL) contents in the canola seeds examined ranged from 49.7 to $78.1 \mathrm{mmol} \mathrm{g}^{-1}$. The extracted canola seed oils revealed an iodine value of 118.2-124.6 g of $\mathrm{I} / 100 \mathrm{~g}$ of oil; refractive index $\left(40^{\circ} \mathrm{C}\right), 1.460-1.464$; density $\left(24^{\circ} \mathrm{C}\right)$, 0.914-0.919 $\mathrm{mg} \mathrm{mL}^{-1}$; saponification value, 187-195; unsaponifiable matter, $0.51-1.10 \%$; acidity (\% as oleic acid), 0.40-1.40, and color (1-in. cell), 1.35-1.73 R + 21.0-38.0 Y. Peroxide value (meq/ $\mathrm{kg}$ of oil) and specific extinctions at 232 and $270 \mathrm{~nm}$ were determined to be 2.00-7.08, 2.17-3.16 and $0.44-0.91$, respectively. The seed oils of the five canola cultivars mainly consisted of oleic (C18:1), linoleic (C18:2) and linolenic (C18:3) acids at levels of 49.16-62.14, 14.6123.45 and $6.97-9.10 \%$, respectively. The concentrations of palmitic (C16:0), stearic (C18:0), erucic (C22:1) and gadoleic (C20:1) acids ranged from 3.47 to $6.00,1.51$ to 2.10 , traces to 13.03 and 1.30 to $10.63 \%$, respectively. A small amount of arachidic acid (20:0) with a contribution below $1 \%$ was also detected. The contents of tocopherols $(\alpha, \gamma$, and $\delta)$ in the canola oils accounted for 77.1-270.3, 191-500, 3.5-15.6 mg $\mathrm{kg}^{-1}$, respectively. The presence of rather high levels of erucic acid and GSL in the present analysis of canola emphasized the need to further reduce the contents of these two antinutritional constituents in the investigated cultivars.

KEY-WORDS: Canola - Characterization - Erucic acid Glucosinolates Physicochemical properties - Oxidative stability - Tocopherols.

\section{INTRODUCTION}

Supra optimal levels of erucic acid in seed oil and glucosiniolates in seed meal of regular rapeseed have almost prohibited the utilization of this crop from human and animal consumption. Some earlier studies on animals show that erucic acid (C22:1), when consumed in large quantities may adversely affect heart tissues and thus promotes myocardial lesions (Kramer et al., 1973; Clandinin and Yamashiro 1982). Glucosinolates (GSL) and their decomposition products can cause several health hazards in animals, including enlargement of the thyroid, and negative effects on adrenal glands and kidneys (Zukalova and Vasak 2002; Barillari et al., 2005).

Canola, a "double-low" variety of the rapeseed (Brassica napus or Brassica campestris), contains 
less than $2 \%$ erucic acid (C22:1) in the oil and less than 30 micromoles per gram of glucosinolates in the seed meal. Due to these characteristics, it has gained considerable recognition as a potential oilseed crop worldwide. (Hu et al., 1997; Neff et al., 1997).

Currently, canola oil which is generally available in the market contains only traces of erucic acid, 5 to $8 \%$ saturated, 60 to $65 \%$ monosaturated, and 30 to $35 \%$ polyunsaturated fatty acids. Canola oil is the preferred oil for health-conscious consumers because it is the lowest in saturated fat among the major edible oils (Shahidi and Shukla, 1996). Canola oil contains appreciable amounts of antioxidants such as vitamin E, phenolic acids, flavonoids and insoluble condensed tannins, all of which are beneficial to human health (Zambiazi, 1997). Rapeseed/canola seed meal, constituting $50-58 \%$ of the weight of seeds is a potential source of essential amino acids like lysine, methionine, cystine, threonine and tryptophan (Sarwar et al., 1984; Larsen and Sorensen, 1985).

In Pakistan, after cotton, rape seed/mustard and canola are the major oilseed crops grown in an area of about 365,000 ha with an annual production of 350,000 tons contributing about $19 \%$ to the overall domestic production of edible oils (PARC, 2007). The oil-seed producers are in continuous efforts to develop true canola cultivars with a reduced content of erucic acid and GSL in order to fulfill international standards. A number of diverse canola cultivars are currently under trials in Pakistan for attaining maximum seed oil under the native environmental conditions, but it is not certain whether the canola cultivars being grown have maintained their desired oil characteristics. In view of this, we sought to characterize such canola cultivars being grown under indigenous environmental regimes. The primary objective of the present study was to conduct a detailed analysis and to investigate the physico-chemical characteristics of canola seed and the seed oils of five commonly grown cultivars with special emphasis on quantifying and comparing the contents of the oil, erucic acid and glucosinolates.

\section{MATERIALS AND METHODS}

\subsection{Collection of canola seeds}

The seeds of five, indigenously grown canola cultivars : Zafar-2002, Bulbul (Frontier), Dunkeld, Oscar and Con-Il were obtained from the Ayub Agricultural Research Institute (AARI), Jhang Road, Faisalabad, Pakistan. Three seed samples for each cultivar were assayed.

\subsection{Reagents and chemicals}

All reagents (analytical and (HPLC) and chemicals used for all analytical procedures were from Merck (Darmstadt, Germany) or Sigma Aldrich (Buchs, Switzerland). Pure standards of tochopherols (DL- $\alpha$-tochopherol, (+)- $\delta$-tochopherol, $\gamma$-tochopherol) and fatty acid methyl esters (FAMEs) were obtained from Sigma Chemical Co. (St. Louis, MO).

\subsection{Proximate analysis of seeds}

\section{Moisture determination}

Moisture content of the seeds was determined at $105^{\circ} \mathrm{C}$ according to ISO method 666 (ISO 1977) using an electric oven (VOC-300 SD; EYELA, Tokyo, Japan).

\section{Extraction of oil}

The seeds of all five canola cultivars were crushed in a domestic electric grinder. The crushed seed material was conditioned $\left(100^{\circ} \mathrm{C}\right)$ in an electric oven (VOC-300 SD; EYELA, Tokyo, Japan) for 30 minutes. After conditioning, the ground seed material $(\sim 75 \mathrm{~g})$ was fed into a Soxhlet extractor. The extraction was performed with $300 \mathrm{~mL}$ of $n$ hexane (B.P. $68^{\circ} \mathrm{C}$ ) on a water bath for $6 \mathrm{~h}$. The oils extracted were stored in a refrigerator at $4^{\circ} \mathrm{C}$ until further analysis.

\section{Determination of glucosinolates in canola seeds}

The glucosinolates were determined after their hydrolysis with myrosinase by milling the whole canola seeds separately with water and acidified $40 \%$ methanol to liberate bound and free glucose. The extracts were filtered through activated charcoal paper to remove any interfering phenolics. The total glucosinolate contents were estimated following a glucose oxidase/peroxidas calorimetric method (Smith and Dacombe 1987).

\section{Analysis of oilseed residues}

After oil extraction, the canola oilseed residues were analyzed for protein, fiber, and ash contents. Protein content $(\mathrm{N} \times 6.25)$ was determined according to the AOAC method 954.01 (AOAC, 1990). Fiber content was estimated by an ISO method 5983 (ISO, 1977). Briefly, a fat-free, finely ground sample $(2.5 \mathrm{~g})$ of meal was weighed and boiled with sulfuric acid $\left(0.255 \mathrm{~mol} \mathrm{~L}^{-1}\right)$, followed by separation and washing of the insoluble residue. The residue was further boiled with sodium hydroxide $\left(0.313 \mathrm{~mol} \mathrm{~L}^{-1}\right)$, followed by separation, washing, and drying. The dried residue was weighed and ashed in a muffle furnace (TMF-2100, Eyela, Tokyo, Japan) at $600^{\circ} \mathrm{C}$, and the loss of mass was determined. The determination of ash content was made following the ISO method 749 (ISO, 1977). Two grams of meal were carbonized by heating on a gas flame. The carbonized material was then ashed in an electric muffle furnace (TMF2100, Eyela, Tokyo, Japan) at $550^{\circ} \mathrm{C}$, to achieve a constant mass. 


\subsection{Analysis of extracted oils}

\section{Physical and chemical characteristics}

The density, refractive index, iodine value, peroxide value, acidity, saponification value and unsaponifiable matter of the extracted canola oils were determined following the AOCS official methods Cc 10a-25, Cc 7-25, Cd 1-25, Cd 8-53, F 9a-44, Cd 3-25, and Ca 61-40, respectively (AOCS, 1997). The color intensities (Red +Yellow, 1-in. cell) of the oils were determined by a Lovibond tintometer (Tintometer Ltd., Salisbury, Wiltshire, United Kingdom). Specific extinctions at 232 and $270 \mathrm{~nm}$ were determined using a spectrophotometer (U-2001, Hitachi Instruments, Inc., Tokyo, Japan). Absorbance of the oils, diluted with iso-octane, was recorded in the UV region at 232 and $270 \mathrm{~nm}$. Specific extinctions $\left(\varepsilon^{1 \%} 1 \mathrm{~cm}(\lambda)\right)$ were calculated following the standard IUPAC method (IUPAC, 1987).

\section{Fatty acid composition}

Canola oils were transmethylated according to the standard IUPAC method 2.301 (IUPAC, 1987) and analyzed on a SHIMADZU gas chromatograph model 17-A, fitted with an SP-2330 (SUPELCO Inc. Supelco Park Bellefonte, PA 16823-0048, USA) polar capillary column $(30 \mathrm{~m} \times 0.32 \mathrm{~mm} ; 0.20 \mu \mathrm{m})$, and a flame ionization detector. Oxygen-free nitrogen was used as a carrier gas at a flow rate of $3.0 \mathrm{~mL} \mathrm{~min} \mathrm{~min}^{-1}$. The column temperature was programmed from 180 to $220^{\circ} \mathrm{C}$ at a linear increment of $5^{\circ} \mathrm{C} \mathrm{min}^{-1}$. The initial and final retention times were 2 and 10 minutes, respectively. Injector and detector temperatures were maintained at 230 and $250^{\circ} \mathrm{C}$, respectively. A sample volume of $1.0 \mu \mathrm{L}$ was injected using split mode (split ratio, 1:65). Fatty acid methyl esters (FAMEs) were identified by comparing their relative and absolute retention times to those of authentic standards. A datahandling software ((Data APEX Ltd., Prague, The Czech Republic), Chromatography Station for Windows (CSW32) was used for the quantification.

\section{Tocopherols content}

Tocopherols $(\alpha, \gamma$ and $\delta$ ) in the oil samples were analyzed by high performance liquid chromatography following Lee et al. (2003). An HPLC (Sykam GmbH, Kleinostheim, Germany) equipped with an S-1121 dual piston solvent delivery system and S-3210 UV/Vis diode array detector was used. One gram of oil was made up to a volume of $10 \mathrm{~mL}$ with acetonitrile in a volumetric flask, wrapped in aluminum foil to inhibit photoxidation. $20-\mu \mathrm{L}$ of filtered sample were injected into an analytical Hypersil (Thermo Hypersil, GmbH, Germany) ODS reverse phase (C18) column $(250 \times 4.6 \mathrm{~mm} ; 5 \mu \mathrm{m}$ particle size $)$ fitted with a C18 guard column. The mobile phase comprising a mixture of HPLC grade methanol and acetonitrile $(65: 35 \mathrm{v} / \mathrm{v})$ was applied at a flow rate of $1.3 \mathrm{~mL} \mathrm{~min}^{-1}$ at $30^{\circ} \mathrm{C}$ under isocratic elution. Detection was made at $292 \mathrm{~nm}$. Tocopherols $(\alpha-, \gamma-$, and $\delta$ ) were identified by comparing the retention times and quantified on the basis of the peak area percent of the unknowns compared with those of pure standards (Sigma Chemical Co., St. Louis, $\mathrm{MO})$. The quantification was done on a computer using SRI peak simple chromatography data acquisition and integration software (SRI Instrument, Torrance, California, USA).

\subsection{Statistical Analysis}

Three canola oilseed samples were assayed for each cultivar and analyzed individually in triplicate. Data is reported as mean $(n=1 \times 3 \times 3) \pm S D$ $(n=1 \times 3 \times 3)$. One way ANOVA was used to determine significant differences among the cultivars considering a level of significance less than $5 \%(p<0.05)$, using the statistical software STATISTICA (StatSoft, OK, USA).

\section{RESULTS AND DISCUSSION}

The data for the analysis of seeds and seed oils of five indigenously grown canola cultivars: Zafar2002, Bulbul (Frontier), Dunkeld, Con-II and Oscar are summarized in Tables 1-5. The hexane-extracted oil content of canola seeds from the five investigated cultivars ranged from $34.3 \%$ (Con-II) to $39.3 \%$ (Dunkeld) (Table 1). The variation in the oil content within different canola oilseed cultivars may be attributed to their varied genetic make-up, and to different growing and agro-ecological conditions. The range of oil content (34.3-39.3\%) in the present analysis of canola oilseeds was comparable to that reported in the literature (Pritchard, 1991). Our findings showed the highest concentration of oil in Dunkeld and the lowest in Con-11, however, Hassan et al., (2005) reported somewhat higher oil contents in Bulbul (Frontier) and lower in Zafar-2002. The variations in the oil contents of different canola cultivars in the present study could be supported from the investigations of Pritchard et al. (2000).

The analysis of canola oilseed residues (Table 1) revealed that the protein content $(22.0-41.0 \%)$ of the seeds varied significantly $(p<0.05)$ among cultivars analyzed. Whereas the fiber, ash and moisture contents of the seeds, $12.0-14.0 \%, 3.0-3.5 \%$ and $4.0-7.5 \%$, respectively did not vary considerably. The protein content in the present analysis (22.0$41.0 \%$ ), when compared with conventional oilseed crops was found to be higher than those of safflower (20-22\%), sunflower (16-19\%), cottonseed (19\%), linseed (24\%) and sesame (20-25\%) (Pritchard, 1991). The rapeseed/canola meal is already reported to be a rich source of essential amino acids such as lysine, methionine, cystine, threonine and tryptophan; the concentrations of which are quite similar to other cereals (Sarwar et al., 1984; Larsen and Sorensen, 1985). 
Table 1

Proximate composition of canola oilseeds from different cultivars

\begin{tabular}{lccrrr}
\hline \multicolumn{1}{c}{ Constituents } & Zafar-2002 & Bulbul (Frontier) & \multicolumn{1}{c}{ Dunkeld } & \multicolumn{1}{c}{ Oscar } & \multicolumn{1}{c}{ Con-11 } \\
\hline Oil content (\%) & $35.3 \pm 0.3^{\mathrm{b}}$ & $38.3 \pm 0.2^{\mathrm{a}}$ & $39.3 \pm 0.7^{\mathrm{a}}$ & $38.2 \pm 0.8^{\mathrm{a}}$ & $34.3 \pm 0.3^{\mathrm{b}}$ \\
Moisture content (\%) & $4.0 \pm 0.1^{\mathrm{d}}$ & $4.0 \pm 0.1^{\mathrm{d}}$ & $4.5 \pm 0.2^{\mathrm{a}}$ & $6.0 \pm 0.1^{\mathrm{c}}$ & $7.5 \pm 0.2^{\mathrm{b}}$ \\
Fiber content (\%) & $12.5 \pm 0.2^{\mathrm{bc}}$ & $13.5 \pm 0.3^{\mathrm{ab}}$ & $12.0 \pm 0.2^{\mathrm{c}}$ & $13.0 \pm 0.4^{\mathrm{b}}$ & $14.0 \pm 0.3^{\mathrm{a}}$ \\
Ash content (\%) & $3.1 \pm 0.1^{\mathrm{ab}}$ & $3.4 \pm 0.2^{\mathrm{ab}}$ & $3.0 \pm 0.2^{\mathrm{b}}$ & $3.0 \pm 0.1^{\mathrm{b}}$ & $3.5 \pm 0.2^{\mathrm{a}}$ \\
Proteins content (\%) & $30.2 \pm 1.3^{\mathrm{b}}$ & $22.1 \pm 1.4^{\mathrm{d}}$ & $41.0 \pm 2.1^{\mathrm{a}}$ & $29.0 \pm 1.5^{\mathrm{b}}$ & $26.0 \pm 1.3^{\mathrm{c}}$ \\
$(\mathrm{N} \times 6.25)$ & & & & \\
Glucosinolates content & $49.7 \pm 3.4^{\mathrm{c}}$ & $51.5 \pm 4.3^{\mathrm{c}}$ & $58.7 \pm 3.0^{\mathrm{b}}$ & $62.4 \pm 3.2^{\mathrm{b}}$ & $78.1 \pm 4.0^{\mathrm{a}}$ \\
$(\mu$ moles/g) & & & & \\
\hline
\end{tabular}

Values (mean $\pm S D$ ) are from three canola seed samples of each cultivar, analyzed individually in triplicate.

Mean values followed by different superscript letters in the same row indicate significant difference $(p<0.05)$ among cultivars

Table 2

Physicochemical characteristics of canola seed oils from different cultivars

\begin{tabular}{|c|c|c|c|c|c|}
\hline Constituents & Zafar-2002 & Bulbul (Frontier) & Dunkeld & Oscar & Con-11 \\
\hline Refractive index $\left(40^{\circ} \mathrm{C}\right)$ & $1.464 \pm 0.03^{\mathrm{a}}$ & $1.460 \pm 0.02^{\mathrm{a}}$ & $1.464 \pm 0.04^{\mathrm{a}}$ & $1.462 \pm 0.03^{\mathrm{a}}$ & $1.463 \pm 0.03^{\mathrm{a}}$ \\
\hline Density $(\mathrm{mg} / \mathrm{mL})\left(24^{\circ} \mathrm{C}\right)$ & $0.919 \pm 0.02^{\mathrm{a}}$ & $0.917 \pm 0.04^{\mathrm{a}}$ & $0.914 \pm 0.03^{a}$ & $0.919 \pm 0.02^{\mathrm{a}}$ & $0.916 \pm 0.02^{a}$ \\
\hline $\begin{array}{l}\text { lodine value } \\
\text { ( } \mathrm{g} \text { of } \mathrm{I} / 100 \mathrm{~g} \text { of oil) }\end{array}$ & $121.6 \pm 1.6^{\mathrm{ab}}$ & $118.2 \pm 2.6^{b}$ & $120.5 \pm 1.9^{b}$ & $122.6 \pm 2.0^{\mathrm{ab}}$ & $124.6 \pm 1.9^{a}$ \\
\hline $\begin{array}{l}\text { Saponification value } \\
\text { (mg of } \mathrm{KOH} / \mathrm{g} \text { of oil) }\end{array}$ & $193.0 \pm 3.3^{\mathrm{ab}}$ & $189.0 \pm 2.9^{a b}$ & $187.0 \pm 3.2^{b}$ & $188.0 \pm 4.0^{\mathrm{ab}}$ & $195.0 \pm 4.0^{a}$ \\
\hline $\begin{array}{l}\text { Unsaponifiable matter (\%) } \\
\text { Color (1-in. cell) }\end{array}$ & $0.51 \pm 0.04^{c}$ & $0.70 \pm 0.04^{b}$ & $1.10 \pm 0.10^{b}$ & $0.90 \pm 0.10^{b}$ & $0.70 \pm 0.05^{a}$ \\
\hline Red unit & $1.71 \pm 0.16^{\mathrm{a}}$ & $1.62 \pm 0.06^{\mathrm{ab}}$ & $1.60 \pm 0.14^{\mathrm{ab}}$ & $1.35 \pm 0.12^{b}$ & $1.73 \pm 0.12^{\mathrm{a}}$ \\
\hline Yellow unit & $35.0 \pm 0.5^{b}$ & $21.0 \pm 1.0^{c}$ & $23.0 \pm 0.7^{c}$ & $22.0 \pm 0.3^{c}$ & $38.0 \pm 0.5^{a}$ \\
\hline $\begin{array}{l}\text { Acidity } \\
\text { (\% as oleic acid) }\end{array}$ & $0.40 \pm 0.02^{d}$ & $0.68 \pm 0.03^{c}$ & $1.21 \pm 0.04^{b}$ & $0.66 \pm 0.03^{c}$ & $1.40 \pm 0.04^{a}$ \\
\hline
\end{tabular}

Values (mean $\pm \mathrm{SD}$ ) are of three canola oil samples from each cultivar, analyzed individually in triplicate.

Mean values followed by different superscript letters in the same row indicate significant difference $(p<0.05)$ among cultivars.

The glucosinolate (GSL) contents of the canola seeds of the different cultivars ranged from 49.7 to $78.1 \mathrm{mmoles} \mathrm{g}^{-1}$ of dry seed weight (Table 1). The lowest content of GSL (49.7) was detected in cultivar Zafar-2002, whereas, that of Con-II offered the highest level (78.1). The present levels of GSL for Oscar, Dunkeld, and Con-II were in agreement with the findings of Hassan et al., (2005), while for Zafar-2002 and Bulbul (Frontier) the present values were quite different. True canola cultivars should have GSL contents less than $30 \mathrm{mmoles} / \mathrm{g}$ of airdried meal (Pritchard, 1991). However, the present analysis showed that none of the canola cultivars examined here were a true canola because of the presence of quite high contents of GSL. The significant differences $(p<0.05)$ of GSL contents among the cultivars examined could be due to the diverse genetic makeup of the cultivars, and to specific agroecological and environmental conditions of the regions. Glucosinolates are antinutritional components present in high amounts in rapeseed/canola meal, but not in considerable amounts in canola oil. Glucosinolate accumulation is known to be affected by water/moisture availability, particularly at the seed development and maturation stages. The glucosinolate levels in seeds can be controlled during growth stages through applications of jasmonic acid (Pritchard et al., 2000; Harbans and Hamama 2003).

Various physicochemical attributes of the extracted canola seed oils are given in Table 2 . The values determined for iodine, refractive index $\left(40^{\circ} \mathrm{C}\right)$, density $\left(24^{\circ} \mathrm{C}\right)$, saponification value and unsaponifiabe matter for the canola seed oils of the investigated cultivars were found to be 118.2 to 124.6 ( $\mathrm{g}$ of I/ $100 \mathrm{~g}$ of oil), 1.462 to $1.464,0.914-0.919,187$ to 195 (mg of $\mathrm{KOH} / \mathrm{g}$ of oil), and $0.51-1.10 \%$, respectively. The iodine values (118.2-124.6) for canola oils in the present analysis were somewhat comparable with those reported in the literature (Rossell, 1991). The refractive indexes (1.462-1.464) for the investigated canola seed oils were almost comparable with those of cottonseed (1.458-1.466), corn (1.465-1.468), mustard seed (1.461-1.469), high and low erucic acid rapeseed (1.465-1.467) oils (Rossell, 1991). The saponification values were noted to be comparable with those of cottonseed (189-198), olive (184-189), pumpkin seed (185-198) 
Table 3

Oxidation state of canola seed oils from different cultivars

\begin{tabular}{|c|c|c|c|c|c|}
\hline Constituents & Zafar-2002 & Bulbul (Frontier) & Dunkeld & Oscar & Con-11 \\
\hline $\begin{array}{l}\text { Conjugated dienes } \\
\varepsilon^{1 \%}{ }_{1 \mathrm{~cm}}(\lambda 232)\end{array}$ & $2.40 \pm 0.20^{b}$ & $2.17 \pm 0.20^{b}$ & $2.26 \pm 0.15^{b}$ & $2.29 \pm 0.18^{b}$ & $3.16 \pm 0.28^{\circ}$ \\
\hline $\begin{array}{l}\text { Conjugated trienes } \\
\varepsilon^{1 \%}{ }_{1 \mathrm{~cm}}(\lambda 270)\end{array}$ & $0.51 \pm 0.04^{d}$ & $0.91 \pm 0.10^{\mathrm{a}}$ & $0.44 \pm 0.04^{c}$ & $0.54 \pm 0.05^{d}$ & $0.64 \pm 0.10^{b}$ \\
\hline $\begin{array}{l}\text { Peroxide value (meq/kg } \\
\text { of oil) }\end{array}$ & $7.08 \pm 0.19^{a}$ & $4.70 \pm 0.20^{\circ}$ & $6.00 \pm 0.11^{b}$ & $4.10 \pm 0.17^{d}$ & $2.00 \pm 0.21^{e}$ \\
\hline
\end{tabular}

Values (mean \pm SD) are of three canola oil samples from each cultivar, analyzed individually in triplicate.

Mean values followed by different superscript letters in the same row indicate significant difference $(p<0.05)$ among cultivars.

Table 4

Fatty acid (FA) composition ( $\mathrm{g} / 100 \mathrm{~g}$ of FA) of canola seed oils from different cultivars

\begin{tabular}{lcccrr}
\hline Fatty Acids & Zafar-2002 & Bulbul (Frontier) & Dunkeld & \multicolumn{1}{c}{ Oscar } & \multicolumn{1}{c}{ Con-11 } \\
\hline C16:0 & $4.80 \pm 0.39^{\mathrm{c}}$ & $3.47 \pm 0.40^{\mathrm{d}}$ & $5.24 \pm 0.24^{\mathrm{b}}$ & $4.84 \pm 0.22^{\mathrm{c}}$ & $6.00 \pm 0.30^{\mathrm{a}}$ \\
C18:0 & $1.80 \pm 0.13^{\mathrm{b}}$ & $1.62 \pm 0.05^{\mathrm{c}}$ & $2.10 \pm 0.11^{\mathrm{a}}$ & $1.51 \pm 0.10^{\mathrm{d}}$ & $1.67 \pm 0.10^{\mathrm{c}}$ \\
C18:1 & $59.71 \pm 0.81^{\mathrm{b}}$ & $49.16 \pm 1.10^{\mathrm{c}}$ & $59.00 \pm 1.00^{\mathrm{b}}$ & $58.62 \pm 0.74^{\mathrm{b}}$ & $62.14 \pm 0.85^{\mathrm{a}}$ \\
C18:2 & $19.38 \pm 0.45^{\mathrm{c}}$ & $14.61 \pm 0.81^{\mathrm{d}}$ & $21.00 \pm 0.50^{\mathrm{b}}$ & $23.45 \pm 0.70^{\mathrm{a}}$ & $21.25 \pm 0.65^{\mathrm{b}}$ \\
C18:3 & $9.10 \pm 0.51^{\mathrm{a}}$ & $6.97 \pm 0.32^{\mathrm{c}}$ & $8.00 \pm 0.36^{\mathrm{b}}$ & $9.00 \pm 0.29^{\mathrm{a}}$ & $6.98 \pm 0.49^{\mathrm{c}}$ \\
C20:0 & $0.55 \pm 0.10^{\mathrm{a}}$ & $0.51 \pm 0.10^{\mathrm{a}}$ & $0.65 \pm 0.09^{\mathrm{a}}$ & $0.60 \pm 0.14^{\mathrm{a}}$ & $0.56 \pm 0.10^{\mathrm{a}}$ \\
C20:1 & $1.61 \pm 0.28^{\mathrm{c}}$ & $10.63 \pm 0.40^{\mathrm{a}}$ & $1.50 \pm 0.12^{\mathrm{c}}$ & $1.85 \pm 0.12^{\mathrm{b}}$ & $1.30 \pm 0.23^{\mathrm{d}}$ \\
C22:1 & $3.05 \pm 0.18^{\mathrm{b}}$ & $13.03 \pm 0.21^{\mathrm{a}}$ & $2.51 \pm 0.10^{\mathrm{c}}$ & $\operatorname{tr}$ & $\operatorname{tr}$
\end{tabular}

Values (mean $\pm \mathrm{SD}$ ) are of three canola oil samples of each cultivar, analyzed individually in triplicate, (tr traces)?

Mean values followed by different superscript letters in the same row indicate significant difference $(p<0.05)$ among cultivars.

and safflower seed (186-198) oils (Rossell, 1991). The free fatty acid contents (as oleic acid) of the tested canola oils ranged from 0.40 to $1.40 \%$, which could not be compared with literature reports. Of the canola seed oils, cultivar Zafar-2000 exhibited the lowest acid value, indicating better resistance to hydrolysis for this oil. Generally, higher acid values indicate a high magnitude of hydrolytic deterioration and thus poor quality oils (Rossell, 1991).

The color values of the canola seed oils were found to be 1.35-1.71 red units and 21.0-38.0 yellow units. Color growth in vegetable oils is mainly due to the occurrence of a variety of pigments such as chlorophyll and carotenoids. Such pigments are efficiently removed using different treatments like refining and bleaching of oils. From the viewpoint of commercial applications, the oils with the least coloration are more appealing.

The peroxide value, which is generally used to express the magnitude of primary oxidation products in oils (McGinely, 1991), ranged from 2.00 to $7.08 \mathrm{meq} \mathrm{kg} \mathrm{in}^{-1}$ the canola seed oils investigated (Table 3). The specific extinctions at 232 and 272 $\mathrm{nm}$, which are important indicators of oxidative deterioration of oils (McGinely, 1991; Manzoor et al., 2007), ranged from 2.17-3.16 and 0.44-0.91, respectively (Table 3 ). There are no previously reported data on these canola cultivars to compare the results of peroxide value and conjugated diene and triene contents with our findings reported here.

Table 4 depicts the fatty acid composition of the seed oils from different canola cultivars. The tested canola seed oils mainly consisted of oleic (C18:1), linoleic (C18:2) and linolenic (C18:3) acids at levels of $49.16-62.14,14.61-23.45$ and $6.97-9.10 \%$, respectively. The concentrations of palmitic (C16:0), stearic (C18:0), erucic (C22:1) and gadoleic $(\mathrm{C} 20: 1)$ acids ranged from 3.47 to $6.00,1.51$ to 2.10, traces to 13.03 and 1.30 to $10.63 \%$, respectively. A small amount of arachidic acid (20:0) with a contribution below $1 \%$ was also detected.

The levels of $\mathrm{C} 16: 0$ and $\mathrm{C} 18: 0$ in the present analysis of canola seed oils was quite comparable with those for canola oil reported in the literature (Rossell, 1991). The contents of oleic acid (C18:1 n9 ), ranging from $49.16-62.14 \%$, varied significantly $(p<0.05 \%)$ among the canola cultivars analyzed. The highest amount of oleic acid was detected in Con-11 (62.14\%), whereas, the lowest in Bulbul (Frontier) (49.16\%). The content of oleic acid in our present analysis was slightly different from that reported by Hassan et al., (2005). However, the present range of oleic acid was in agreement with those reported in the literature (Rossell, 1991; Pritchard et al., 2000). Oleic acid is the most abundant fatty acid in nature and is present in almost all vegetable oils and fats. Oleic acid is gaining importance in human nutrition owing to its potential health benefits against cardiovascular heart diseases and its cholesterol lowering effects (Kris-Etherton 1999; Lovejoy 2002).

The contents of C18:2 $n-6$ in the tested canola seed oils (14.61-23.45\%) varied significantly $(p<0.05)$ among cultivars analyzed with the highest 
levels (23.45\%) in Oscar and the lowest (14.61\%) in Bulbul (Frontier). The highest level (9.10\%) of C18:3 $n$-3 was observed in Zafar-2002, whereas the lowest $(6.97 \%)$ was observed in Bulbul (Frontier), showing significant $(p<0.05)$ variations among cultivars. Our present analysis showed that the contents of $C 18: 3$ $n-3$ determined in the canola cultivars were comparable with those reported by Hassan et al., (2005). Both, C18:2 n-6 and C18:3 n-3 are the essential fatty acids that the human body is unable to synthesize. The potential health benefits of essential fatty acids are well documented elsewhere (Markwell et al., 1998; Schaefer 2002).

Erucic acid (C22:1) was detected in the range of traces to $13.03 \%$ with the highest level $(13.03 \%)$ in Bulbul (Frontier), with the lowest (traces) in Oscar and Con-11. True canola contains less than $2 \%$ erucic acid (C22:1). It was observed from the present fatty acid data that only two of the five tested canola cultivars exhibited erucic acid levels below $2 \%$ and could therefore be defined as true canola.

The data also revealed significant $(p<0.05)$ differences among cultivar means for gadoleic acid (C20:1), ranging from $1.30 \%$ in Con-11 to $10.63 \%$ in Bulbul (Frontier). The exceptionally high amount of gadoleic acid $(10.63 \%)$ determined in the present analysis of Bulbul (Frontier) as compared to the other canola cultivars tested might be attributed to the presence of higher levels of erucic acid. This fact is supported by the findings of Rossell (1991), who reported higher levels of gadoleic acid (2.6-9.4\%) in those canola cultivars, which possess elevated amounts of erucic acid (6.5-51.6\%) as compared to those containing low erucic acid (tr-4.7\%).

Table 5 presents the levels of tocopherols in the seed oils of different canola cultivars. The contents of $\alpha$ tocopherol, $\gamma$-tocopherol, and $\delta$-tocopherol ranged from $77.1-270.3,190.6-500.0,3.5-15.6 \mathrm{mg} \mathrm{kg}^{-1}$ of oil, respectively. The concentration of $\alpha$-tocopherol, which has greater vitamin $E$ effectiveness (Rossell, 1991) was found to be the lowest in Zafar-2000, and the highest in Dunkeld. The amount of $\gamma$-tocopherol was noted to be higher in Oscar $\left(500.0 \mathrm{mg} \mathrm{kg}^{-1}\right)$ and Con-11 (420.0 mg kg-1), whereas Dunkeld offered the lowest level of this isomer of tocopherol (190.0 $\mathrm{mg} \mathrm{kg}^{-1}$ ). The concentration of $\delta$-tocopherol having superior antioxidant activity over $\gamma$ - or $\alpha$-tocopherol (Anwar et al., 2006), was quite low (3.5-15.6 mg $\mathrm{kg}^{-1}$ ). No previously reported data on the tocopherol contents of these cultivars of canola seed oils with which to compare the values of the present analysis have been reported. Overall, the tocopherol profiles of Oscar and Con-11 seed oils were quite comparable to those reported for canola oils in the literature (Rossell, 1991).

From the values of erucic acid and GSL contents of the investigated canola cultivars, grown in Pakistan, it is possible to declare that none of the tested cultivars is true canola because the contents of both of these antinutritional components are above the permissible limits as established by current specifications of the Canola Council of Canada. Of course these cultivars are in the developing stage in Pakistan and such variation in the contents of components may be attributed to the varied geographical and cultivation regimes. This necessitates the need to further reduce and control the contents of GSL and erucic acid in these locally grown canola cultivars, where applicable. The present information might be useful in controlling and maintaining the required attributes of growing canola cultivars under indigenous conditions and environment for the on-going breeding programs and for researchers.

\section{REFERENCES}

AOAC. 1990. Official Methods of Analysis of the Association of Official Analytical Chemists (AOAC), 15th Ed., AOAC Inc., Arlington, VA.

AOCS. 1997. Official and Recommended Practices of the American Oil Chemists Society (AOCS), $5^{\text {th }}$ Ed., AOCS Press, Champaign, IL,USA.

Anwar F, Latif S, Ashraf M. 2006. Analytical characterization of hemp (Cannabis sativa) seed oil from different agro-ecological zones of Pakistan. J. Am. Oil Chem. Soc. 83, 323-329.

Barillari J, Iori R, Rollin P., Hennion F. 2005. Glucosinolates in the sub-antarctic crucifer Kerguelen cabbage (Pringlea antiscorbutica). J. Nat. Prod. 68, 234-236.

Clandinin MT, Yamashiro S.1982. Dietary factors affecting the incidence of dietary fat-induced myocardial lesions. J. Nutr. 112, 825-828.

Harbans LB, Anwar AH. 2003. Accumulation of glucosinolate, oil, and erucic acid in developing Brassica seeds. Ind. Crop. Prod. 17, 47-51.

Hassan F, Ali H, Cheema AM, Manaf A. 2005. Effects of environmental variation on oil content and fatty acid composition of canola cultivars. J. Res. Sci. 16, 65-72.

Hu FB, Stampfer MJ, Manson JE, Rimm E, Colditz GA. 1997. Dietary fat intake and the risk of coronary heart disease in women. New Eng. J. Med. 337, 1491-1499.

Table 5

Tochopherol contents $(\mathrm{mg} / \mathrm{kg})$ of canola seed oils from different cultivars

\begin{tabular}{lrcccc}
\hline \multicolumn{1}{c}{ Tocopherol } & Zafar-2002 & Bulbul (Frontier) & Dunkeld & Oscar & Con-11 \\
\hline$\alpha$-tocopherol & $77.1 \pm 3.9^{\mathrm{e}}$ & $101.0 \pm 5.0^{\mathrm{d}}$ & $270.3 \pm 4.0^{\mathrm{a}}$ & $170.0 \pm 4.3^{\mathrm{b}}$ & $150.5 \pm 6.0^{\mathrm{c}}$ \\
$\gamma$-tocopherol & $276.5 \pm 8.3^{\mathrm{d}}$ & $300.3 \pm 7.3^{\mathrm{c}}$ & $190.6 \pm 10.0^{\mathrm{e}}$ & $500.0 \pm 12.5^{\mathrm{a}}$ & $420.1 \pm 15.0^{\mathrm{b}}$ \\
$\delta$-tocopherol & $6.0 \pm 0.3^{\mathrm{c}}$ & $11.7 \pm 0.3^{\mathrm{b}}$ & $6.3 \pm 0.3^{\mathrm{c}}$ & $15.6 \pm 0.6^{\mathrm{a}}$ & $3.5 \pm 0.4^{\mathrm{d}}$ \\
\hline
\end{tabular}

Values (mean $\pm S D$ ) are of three canola oil samples of each cultivar, analyzed individually in triplicate.

Mean values followed by different superscript letters in the same row indicate significant difference $(p<0.05)$ among cultivars. 
ISO. 1977. International Organization for Standardization (ISO) Oilseed residues- determination of total ash, International Organization for Standardization, Geneva.

IUPAC. 1987. Standard methods for the analysis of oils, fats and derivatives, International Union of Pure and Applied Chemistry (IUPAC). 7th Rev. Enlarged Ed. edited by C. Paquot and A. Hautfenne, Blackwell Scientific, London.

Kramer JKG, Mahadevan S, Hunt JR, Sauer FD, Corner $\mathrm{AH}$, and Charlton KM.1973. Growth rate, lipid composition, metabolism and myocardial lesions of rats fed rapeseed oils (Brassica campestris var. Arlo, Echo and Span, and B. napus var. Oro). J. Nut. 103, 1696-1708.

Kris-Etherton PM. 1999. Monounsaturated Fatty Acids and Risk of Cardiovascular Disease. Circulation Journal of the American Heart Association 1253-1258.

Larsen LM, Sorensen H. 1985. The value of oilseed rape production in Denmark and the EEC. in Sørensen $\mathrm{H}$, (ed.) Advances in the Production and Utilization of Cruciferous Crops, 1-18. Martinus Nijhoff / Dr W. Junk Publishers, Denmark.

Lee BL, New AL, Ong CN. 2003. Simultaneous determination of tocotrienols, tocopherol, retinol and major carotenoids in human plasma. Clin. Chem. 49, 2056-2066.

Lovejoy, JC (2002). "The influence of dietary fat on insulin resistance". Current Diabetes Reports 2,435-440.

Manzoor M, Anwar F, lqbal T, Bhanger MI. 2007. Physicochemical characterization of Moringa concanensis seeds and seed oil. J. Am.Oil Chem. Soc. 84, 413-419.

Markwell PJ, Bauer JER, Senior DF. 1998. The impact of dietary fats and poly unsaturated fatty acids on renal disease. Anim. Physiol. Nutr. 80, 234-238.

McGinely L.1991. Analysis and quality control for processing and processed fats, in Rossell, JB, Pritchard JLR, (Eds.), Analysis of Oilseeds, Fats and Fatty Foods, 460-470, Elsevier Applied Science, New York.

Neff W, Mounts TL, Rinsch WM. 1997. Oxidative stability as affected by triacylglycerol composition and structure of purified canola oil triacylglycerols from genetically modified normal and high stearic and lauric acid canola varieties. Lebensmittel-Wissenschaft undTechnologie 30, 793-799.

PARC. Pakistan Agricultural Research Council (PARC). 2007. Rapeseed-Mustard (Brassicaspecies) parc.gov. pk/1SubDivisions/NARCCSI/CSI/rapeseed.html

Pritchard JLR. 1991. Analysis and properties of oilseeds. in Rossell, JB, Pritchard JLR, (Eds.), Analysis of Oilseeds, Fats and Fatty Foods, 39-102, Elsevier Applied Science, New York.

Pritchard FM, Eagles A, Norton RM, Salisbury PA, Nicolas M. (2000). Environmental Effects on seed composition of Victorian Canola, Aus. J. Exp. Agric. 40, 679-685.

Rossell, JB. 1991. Vegetable oil and fats. in Rossell, JB, Pritchard JLR, (Eds.), Analysis of Oilseeds, Fats and Fatty Foods, 261-319, Elsevier Applied Science, New York.

Sarwar G, Blair R, Friedman M, Gumbmann MR, Hackler LR, Pellett PL, Smith TK. 1984. Inter and intralaboratory variability in rat growth assays for estimating protein quality of foods. J. Assoc. Off. Anal. Chem. 67, 976-981.

Schaefer EJ. 2002. Lipoproteins, nutrition, and heart disease. Am. J. Clin. Nutr. 75, 191-212.

Shahidi F, Shukla VKS.1996. Non-triacylglycerol constituents of fats and oils. International News on Fats, Oils and Related Materials, 7, 1227-1231.

Smith CA, Dacembe C. 1987. Rapid method for determination of total glucosinolates in rapeseed by measuring of enzymatically released glucose. J. Sci. Food Agric. 38,141-150.

Zambiazi RC. 1997. The role of endogenous lipid components on vegetable oil stability. PhD. Thesis, University of Manitoba, Winnipeg, Manitoba, Canada.

Zukalova H, Vasak J. 2002. The role and effects of glucosinolates of Brassica species-a review. Rostlinna Vyroba 48, 175-180.

Recibido: 28/1/08 Aceptado: 11/7/08 